which inured to them. ${ }^{20}$ A receiver is frequently empowered to avoid fraudulent conveyances. $^{2 x}$ The difficulty in applying this theory in the principal case lies in the fact that the only "subsequent creditors" involved were transferees of the very securities the issuance of which might constitute the fraud. In this situation existing fraudulent conveyance law furmishes no precedent. In any event, recovery for the stock, however, would have to rest upon fraudulent intent coloring the entire transaction. ${ }^{22}$

Reliance was also placed by the court upon a local statute which provided that "no corporation shall issue either bonds or stock except for money, labor done, or money and property actually received, and all fictitious increase of stock or indebtedness .... shall be void." ${ }^{\prime 23}$ Creditors and representatives of creditors have been permitted under this statute to cancel bonds given for fraudulently overvalued property. ${ }^{24}$ If the original owners have transferred the obligations to innocent persons who can enforce them, the transferors would be liable for the proceeds, as a fraudulent grantee who has sold the property fraudulently conveyed. ${ }^{25}$ An action for the proceeds of bonds, however, raises a serious question under such a statute. Any sale of bonds to an underwriter at a discount might be subject to attack, and the courts might have some difficulty defining the class of transactions forbidden by the statute.

\title{
SOME ASPECTS OF DELTVERY: SPECIALTIES AND THE UNIFORM WRITTEN OBLIGATIONS ACT ${ }^{2}$
}

Originally, manual transfer or surrender of possession of the instrument was an indispensable element of delivery. ${ }^{2}$ Today; we are prone to treat the problem of delivery wholly as a question of intention and to disregard the necessity for

${ }^{20}$ Brockhurst v. Cox, 7 I N.J. Eq. 703, 64 Atl. I82 (Igo6), aff'd in 72 N.J. Eq. 950, 73 Atl. II7 (Igo7); Bell v. New York Safety Steam Power Co., I83 Fed. 274 (C.C. N.Y. I910);

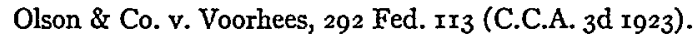

${ }_{2 x}$ Whitman v. Dorsey, IIo Md. 42I, 72 Atl. I042 (I909). In Keedy v. Sterling Electric Appliance Co., $\mathrm{r}_{3}$ Del. Ch. 66, II5 Atl. 359 (I92I), the receiver of a corporation was allowed to set aside a transfer made by the insolvent without compliance with the Bulk Sales Act, on the alternative ground that the conveyance was fraudulent against creditors at common law.

${ }^{22}$ See $5^{6}$ Sup. Ct. $4 x, 49$.

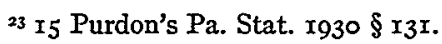

${ }^{24}$ In re Wyoming Valley Ice Co., I53 Fed. 787 (D.C. Pa. I907), aff'd sıb nom. Wiegand v. Albert Lewis Lumber \& Mfg. Co., I58 Fed. 608 (C.C.A. $3^{\text {d }}$ I908) (creditors); Bingaman v. Commonwealth Trust Co., I5 F. (2d) II9 (D.C. Pa. r926) (trustee in bankruptcy); cf. Tepel v. Coleman, 229 Fed. 300 (D.C. Pa. I914) (trustee in bankruptcy), aff'd on other grounds in 230 Fed. 63 (C.C.A. 3 d I9I6).

${ }^{25}$ See cases cited in note rg supra.

I The discussion will be confined chiefly to delivery of instruments under seal, and bills and notes. The problem of delivery is not often associated with simple contracts, because in that

[Footnote I continued on page 489 ]

2 The term delivery designates the final act by which one who has previously signed an instrument, or has both signed and sealed it, gives the instrument its legal operation. See 2 
physical acts. In fact, however, the ancient conception of manual transfer retains considerable force. Modern developments, it is true, have in some jurisdictions identified delivery entirely with intention. ${ }^{3}$ In England, for instance, physical change of possession of the instrument is not a necessary prerequisite to delivery. ${ }^{4}$ In many states in this country, however, while some kind of intention is necessary, intention itself is insufficient for delivery; some manual dealing with the instrument is required. 5 It will be the purpose of this note to discuss two situations in which the influence of the historical relation between delivery

[Footnote I continued from page 488 ]

connection it is generally merged with the problems of offer and acceptance, revocation and rejection. See Biederman v. O'Conner, II 7 Ill. 493 , 7 N.E. 463 (I886). Sometimes, however, the question of whether or not a simple contract has been delivered does arise. Thus, in Cann v. Cann, 40 W.Va. I38, 20 S.E. 910 (I894), a due bill, made by a father in favor of his son was found in the former's account book after his death. The son had no knowledge of its existence until it was found. The court held that the instrument was of no legal effect because it had not been delivered; in Wilbur v. Stoepel \& Watson, 82 Mich. 344, 46 N.W. 724 (189o), it was held that the fact of delivery of stock certificates could not be inferred from mere possession thereof by the obligee, and that it was a fact to be affirmatively proved; in Hacketh v. Jones, 70 Ind. 227 ( 1880 ), a discharged bankrupt executed an agreement in writing binding himself to pay a creditor an indebtedness barred by discharge, which writing he then entrusted to a third person to be delivered on the obligor's death to the creditor. The creditor was not aware of the instrument until it was handed to him, but the court found that there had been a delivery. See also: Springfield v. Harris, I07 Mass. 532 (1871) (written agreement to pay for curbstones to be laid by city); Jenson v. Chicago, M. \& St. Paul Ry. Co., 37 Minn. 383, 34 N.W. 743 ( 1887 ) (contract for sale of land); Wheeler \& Wilson Manufacturing Co. v. Briggs, I8 S.W. 555 (Texas I89I) (obligation signed by sureties).

\section{[Footnote 2 continued from page 488 ]}

Tiffany, Real Property $\S 46 \mathrm{r}$ (1920). In early common law parting with possession, regardless of intent, had significant effects, which seem to have been undesirable and unjust. For example, if the instrument was surrendered to the obligor upon payment and the obligee later regained possession of it, even though such possession was gained by force, the obligee was entitled to payment once more, and the obligor's sole legal remedy was an action of trespass for the taking. Cross v. Powel, Cro. Eliz. 483 (I596); Atkins v. Farr, I Adk. 287 (r738); see Ames, Lectures on Legal History IIo (Igr3) quoting from Licey v. Licey, 7 Barr (Pa.) 25I, 253 ( 1847 ): "Even if a bond, thus delivered [to the obligor] but not cancelled, come again to the hands of the obligee, though it be valid at law, the obligor will be relieved in equity."

If the instrument were lost, the obligation was extinguished. Ames, Lectures in Legal History 105 ( $\mathrm{Igr}_{3}$ ). To be distinguished are the cases of fraud in factum, in which, as far back as Bracton's time, one who was tricked into signing and sealing an instrument of one kind when he thought he was executing an instrument of another kind had a valid defense. 2 Pollock and Maitland, History of English Law 536 (I899).

32 Tiffany, Real Property $\$ 46$ I (I920).

4 Xenos v. Wickham, L.R. 2 H.L. 296 ( 1867 ) (where an insurance policy was held to have been delivered, although the insurer had never surrendered possession); accord: Roberts $\mathrm{v}$. Security Co., [I897] I Q.B. III. See also, Macedo v. Straud, [I922] 2 A.C. 330, 337.

5 Renehan v. McAvoy, II6 Md. 356, 8I Atl. 586 (IgrI); Rountree v. Rountree, 85 S.C. 383,67 S.E. 47 I (1909); Butts v. Richards, 152 Wis. 318 , 140 N.W. I (19r3). This view has been adopted by the American Law Institute. Restatement, Contracts $\$$ IO2 (I932). But for an American case in which intention alone was considered sufficient, see Williams v. Galt, 95 III. I72 (I880) discussed, infra, part III. 
and physical transfer is felt today and to see how that relation may influence the application of the Uniform Written Obligations Act. ${ }^{6}$

\section{I}

One example of the vitality of the original requirement of manual transfer is the rule that there can be no delivery in escrow to the promisee; ${ }^{7}$ that is, as long as there is a voluntary relinquishment of control of the instrument to the promisee, the intent with which it is delivered is immaterial and the obligor is bound, despite the fact that he evinced an intent not to be. ${ }^{8}$ The formulation of such a rule is not difficult to understand in the light of the ancient theory of delivery, in which possession by the obligee was in some cases sufficient of itself to give him ownership in the instrument. Sometimes the courts, in order to achieve what they consider to be more equitable results, draw a fine distinction between delivery in escrow to the promisee and a mere transfer of possession of the instrument to him, actual delivery being subject to a condition precedent.9 Such a distinction is very difficult to justify from a conceptual standpoint. The Illinois courts have adopted ${ }^{\text {xo }}$ the general rule that there can be no delivery in escrow to the promisee and also have subscribed to the general practice of stretching a point at times, in order to reach what seems a desirable result in the particular case before them. Thus in Ryan v. Cooke, ${ }^{\text {II }}$ one of the representative cases in Tllinois, a contract under seal was handed to the promisee as an escrow to be operative when the obligor entered into a contract with the city of Chicago. Although this condition, which was not included in the contract but merely agreed upon orally, was never performed, the court held that there could be no delivery in escrow to the obligee and that therefore the sealed instrument took effect from the time it was handed to the obligee. ${ }^{\mathrm{I2}}$ With such a case, it is hard to reconcile

${ }_{9}^{6}$ U. L. A. $43^{\text {I }}$ (r932); see note, 3 Univ. Chi. L. Rev. $3^{\text {I2 }}$ (I936).

7 Devlin, Real Property $\$ 3$ I4 (3d ed. IgII). A few English cases contain dicta to the contrary. See Bower v. Burdekin, Ir M. \& W. I28, I46 (I843); Watkins v. Nash, L.R. 20 Eq. 262, 267 (1875); London Freehold Leasehold Co. v. Suffield, [I897] 2 Ch. 608, 621; see also 2 Tiffany, Real Property I764 (x920).

82 Page, Contracts § 1207 (I920).

9 Rountree v. Smith, 152 Mll. 493,38 N.E. 680 (1894) (where it was held that there was no delivery when a deed was handed to the grantee on oral condition that it was not to take effect until certain security was given in return); see also, Lee v. Richmond, 9o Ia. 695, 57 N.W. 613 (1894).

10 Stevenson v. Crapnell, II4 Ill. I9, 28 N.E. 379 (I885); Stanley v. White, I60 IIl. 605, 43 N.E. 729 (I896); Fletcher v. Shepherd, I 74 Ill. 262, 5 I N.E. 2 I2 (I898).

${ }^{\text {II }}$ 72 III. 302, 50 N.E. $2 x_{3}$ (1898). See also Stevenson v. Crapnell, II4 Ill. I9, 28 N.E. 379 (1885); Stanley v. White, I60 Ill. 605, 43 N.E. 729 (I896); McCann v. Atherton, Io6 Ill. 3I (I883).

${ }^{32}$ Where the condition of the escrow is to be performed by the grantee or promisee there is no question but that the arrangement is valid. However, where the performance of the condition depends entirely on the will of the obligor there are three possibilities: (r) that there is an 
Mitchell v. Clem, ${ }^{13}$ wherein the grantor handed to the grantee a deed on oral condition that it take effect only if the grantor did not perform his promise to marry the grantee. The court, while acknowledging the rule that there can be no delivery in escrow to the grantee, denied its application to these facts on the ground that the deed had been transferred only as security for the grantor's promise to marry and that it was permissible to show that the deed, although in the grantee's hands, had never been delivered..$^{x_{4}}$

It is difficult to find a valid distinction between these two cases. Superficially, the facts do appear different. In Ryan v. Cooke, ${ }^{15}$ the condition upon which the covenant was to take effect was a positive one; i.e., the doing of an act, that of making a contract, while in Mitchell v. Clem, ${ }^{16}$ the deed was to take effect upon the non-performance of an act, the failure to marry. The desirability of distinguishing between the positive and negative conditions is questionable, particularly when simple changes in language can change the appearance of the condition. ${ }^{17}$

effective delivery in escrow although the instrument is revocable at the will of the obligor. Ruggles v. Lawson, 13 Johns. (N.Y.) 285 (1816); (2) that the conditional delivery is totally ineffective. 2 Tiffany, Real Property $I 768-1769$ (2d ed. 1920). See Bosea v. Lent, 90 N.Y.S. 4r, 44 Misc. Rep. 437 (r903); Fitch v. Bunch, 30 Cal. 209 (r886); (3) that the condition should be entirely disregarded and that an absolute delivery be recognized. Adm'rs of White v. Williams, 3 N.J. Eq. $376(1836)$. The decision in the instant case might have been rested on this latter ground.

${ }^{13} 295$ Ill. I5O, I28 N.E. 8I5 (r920). But see the strong dissenting opinion to the effect that the general rule that there can be no delivery in escrow was applicable to the case before the court. See Jordan v. Davis, Io8 Ill. 336 (1884).

34 The court attempts to avoid the rule prohibiting delivery in escrow to the obligee by finding that the parties did not intend an absolute delivery. A conceivable rationale for the decision, although not expressed in the case, might be found in the well-established rule of mortgages that a deed, absolute on its face, may be proved by parol evidence to have been given as security. Walsh, Mortgages 36 (I934); Helbreg v. Schumann, I50 Ill. I2, 2I, 37 N.E. 9I (I894); Trogdon v. Trogdon, I64 Ill. I44, 45 N.E. 575 (I896). It is doubtful whether any criticism of the case can be made on the ground that the condition of the escrow was within the power of the grantor (that is, the grantor had the power to break his promise to marry) and should, therefore, have been ignored, as in Adm's of White v. Williams, 3 N.J. Eq. $376(1836)$. The grantor had only apparent freedom to perform, or not to perform, the condition, for his failure to perform would give title to the grantee. Moreover, he had placed himself in a dilemma; in no way could he maintain the status quo. Cf. Bosea v. Lent, go N.Y.S. 4I, 44 Misc. 437 (Ig03), where the grantor handed a deed to $A$ to be delivered to his wife if he ever again became intoxicated. The grantor did become intoxicated, but his wife's claim to the deed was denied.

${ }^{25}$ Note II supre ${ }^{16}$ Note 13 supra.

"7 A similar problem has arisen in the past in such injunction cases as Lane v. Newdigate, Io Ves. I92 (1804). The courts of equity were formerly reluctant to enforce specifically affirmative covenants by mandatory injunction and so at times, in order to avoid the appearance of enforcing an affirmative stipulation, phrased the decree in a negative form. Thus, in Lane v. Newdigate, ro Ves. 192 ( 1804 ), the decree read that the defendant "be restrained from ... impeding .... the plaintiff .... by continuing to keep the ... canals . . . out of good repair." A change in the language changed the appearance of the condition. This evasive practice is not followed today. Walsh, Equity 339 (I930). 
So, the condition in the Mitchell case may easily be construed as a positive one; that is, the deed was to take effect when the grantor broke his promise of marriage. A transfer of possession to the grantee or promisee with the intention that legal effect to the transfer should not be attached until performance of a stipulated condition is, of course, fundamentally different from a transaction in which the instrument is merely handed to the grantee or promisee for examination or safekeeping. ${ }^{18}$ In the latter instance, parol evidence is universally permitted to show that no delivery was in fact intended. ${ }^{x 9}$ While it is possible to argue that in the Mitchell case, the deed was handed to the grantee for purposes of safekeeping and that it was to have no legal effect until the grantor indicated his intention of making it operative by his refusal to enter into the marriage, it is conceivable that a similar approach could be used in any case where a deed is handed to the grantee upon parol conditions so that the doctrine of Ryan v. Cooke $e^{20}$ would ultimately be stultified.

It has been contended that prohibiting delivery in escrow to the grantee and, consequently, overriding the grantor's intention is indicative of the persistence of a "primitive formalism" in the law of delivery and that the possibility of delivery in escrow to the grantee should be recognized for there is no more danger of misleading third persons, in such cases, than in those in which the manual transfer is not for delivery at all. ${ }^{2 x}$ This contention seems justified; it would be less confusing to recognize that the rule against delivery in escrow to the grantee has no utility, that it is obsolete and that it is no longer being applied with any consistency, than to complicate legal concepts by drawing hazy distinctions between deliveries in escrow and transfers on condition precedent to delivery.

II

At common law no acceptance was necessary. ${ }^{22}$ Nor is any necessary in England today. ${ }^{23}$ This rule also is understandable as a logical incident of the original concept of delivery; since delivery necessarily involved possession by the grantee, or his agent, it was not unfair to assume acceptance from the fact of possession. In many states in this country, despite the frequent assertions to

${ }^{8}$ Gilbert v. North American Fire Ins. Co., I23 Wend. (N.Y.) 43 (I840); Bovee v. Hinde, I35 Ill. I37, 25 N.E. 694 (I890).

xg 2 Tiffany, Real Property $\$ 46 \mathrm{I}$ (I920); Curry v. Colburn, 99 Wis. 3 I9, 74 N.W. 778 (r898) (where the grantor handed the deed to the grantee, to be examined by his lawyer); see also Elliot v. Murray, 225 Ill. I07, 80 N.E. 77 (rgo6).

20 Note Ir supra.

${ }^{2 x}$ See 2 Tiffany, Real Property I764 (r920); 5 Wigmore, Evidence $\S 2408$ (2d ed. I923); but see Ballantine, Delivery in Escrow and the Parol Evidence Rule, 29 Yale L. J. 826, 834 ( $x 920$ ), justifying the orthodox rule. The American Law Institute had adopted the view that there may be a delivery in escrow to the promisee. Restatement, Contracts $\S$ I03 (I932).

22 Littleton's Tenures $\$ \S 684,685$ (I903 ed.); Butler \& Baker's Case, 3 Co. Rep. 68 (I59r); 2 Tiffany, Real Property $x 789$ (r920).

${ }_{23}$ Siggers v. Evans, 5 E. \& B. $3^{67}$ (I855); Standing v. Bowring, 3I Ch. D. 282 (1886); see Macedo v. Stroud, [I922] 2 A.C. 330,337 . 
the contrary, it seems that acceptance is also not required because, when the promise or grant is beneficial and the promisee or grantee has not dissented, acceptance is presumed, whether or not the grantee knew of the deed. ${ }^{24}$ While the language is that of presumptions, in effect, no acceptance is required. A peculiar doctrine prevails in Illinois. Delivery is regarded as a bilateral act. ${ }^{25}$ When the grant is beneficial and the grantee knows of it, acceptance is presumed $;^{26}$ but if the grantee does not have knowledge of the conveyance, actual acceptance must be proved. ${ }^{27}$ There are two exceptions to this rule; one, when the deed runs to an infant, ${ }^{28}$ and two, where it runs to a charity. ${ }^{29}$ In such cases, despite the grantee's lack of knowledge of the deed, the general presumption of acceptance is applied. The suggestion of a third exception may perhaps be found to be implicit in the promissory note cases. In Williams v. Galt ${ }^{\circ}$ for instance, the payee of a note, a banker, indorsed the instrument to the plaintiff and placed it among other papers which the plaintiff kept at the bank. The next day, and before the plaintiff knew of the note's having been assigned to him, the payee made a general assignment for the benefit of his creditors. The note was not included in the debtor's schedule of property and was not delivered to the general assignee. The banker then delivered the note to the plaintiff. The court held that there was a valid delivery to the plaintiff before the general assignment. It seems impossible to reconcile this case with Talty v. Schoenholz, ${ }^{3 x}$ in which a chattel mortgage was made to the plaintiff, mailed to her and placed on her desk. Subsequently, but prior to the plaintiff's knowledge of these facts, a judgment was obtained against the mortgagor and execution levied, against the property secured by the mortgage. In an action against the sheriff to recover possession of the property, the judgment was held to take precedence over the mortgage because acceptance, which is necessary to delivery, will not be presumed where the obligee has no knowledge of the instrument. In both cases, the rights of third parties intervened before actual acceptance and in neither was there knowledge of the acts

${ }_{24}$ Elsberry v. Boykin, 65 Ala. 336 (I880); Russell v. May, 77 Ark. 89, 90 S.W. 6I7 (I905); Tibbals v. Jacobs, 31 Conn. 428 (1863); Wuester v. Folin, 60 Kan. 334, 56 Pac. 490 (I899); Munoz v. Wilson, III N.Y. 295 , I8 N.E. 855 (I888).

${ }^{25}$ Long, The Delivery of Deeds in Illinois, 8 Ill. L. Rev. I59 (rgr3).

${ }^{26}$ Hill v. Kreiger, 250 Ill. 408, 95 N.E. 468 (Igrx); Moore v. Flynn, 135 Ill. 74, 25 N.E. 844 (I8go).

${ }^{27}$ Herbert v. Herbert, I Ill. 278 (r83o); Moore v. Flynn, I35 Ill. 74, 25 N.E. 844 (189o).

${ }^{28}$ Abrams v. Beale, 224 Ill. 496, 79 N.E. 67 I (I906).

29 Thompson v. Candor, $60 \mathrm{Ill}$. 244 ( $187 \mathrm{r}$ ). These exceptions are explicable on the basis of a public policy which favors infants and charitable institutions.

${ }^{30} 95$ Ill. 172 (I880).

${ }^{31} 3^{23}$ Ill. 232, I 54 N.E. I39 (I926). In view of the court's opinion (expressed at 242 ) that the defendant under the circumstances had the burden of showing the absence of delivery, it must have been assumed that the time when the instrument reached the plaintiff's desk was immaterial; or, as in the statement here made, that the instrument reached the desk before the judgments were "delivered to the sheriff and became a lien on the property." See $i d .244$. 
done, yet the cases reach different results. Williams v. Galt, ${ }^{32}$ the promissory note case, seems inconsistent with the Illinois view that delivery is a bilateral act. ${ }^{33}$ Of course, if it were shown that the payee was the indorsee's agent, then knowledge by the indorsee would be unnecessary. ${ }^{34}$ Apart from these possible exceptions, the Illinois courts appear to have required acceptance.

\section{III}

It is noteworthy that Williams v. Galt35 follows the English cases which hold intention sufficient to effect delivery and dispense with the necessity not only of acceptance by the obligee, but of manual transfer as well. In this respect, the decision is opposed to the weight of American authority, ${ }^{36}$ but seems to reach a practically desirable result. There is little benefit in requiring that the grantor or promisor part with control of the instrument; relinquishment of possession of the deed or contract should simply be one of the operative facts having evidential relation to the final ascertainment of whether the obligor intended to deliver the instrument.

Some interesting speculation concerning the function of delivery and the necessity of parting with control of the instrument arises in connection with Uniform Written Obligations Act. ${ }^{37}$ The act eliminates the necessity for consideration where the right of action is based on a written promise containing an additional express statement that the signer intends to be legally bound. Since a promise to be legally bound is, in itself, binding, the problem therefore arises: when shall the promise take effect? The mere drafting of the instrument should not, as a matter of fair play, subject the promisor to liability if, in fact, he manifested by other acts an intention not to be bound. The mere inclusion of a separate statement that he intends to be bound should not make the instrument legally operative any more than does the placing of a seal on a deed or formal contract.

The requirement of the additional express statement that the signer intends to be legally bound was probably designed to insure deliberation by the promisor and to prevent his being bound against his fully formed intention..$^{8}$ It has been suggested that a more efficient means of insuring deliberation would be to require a "locus poenitentiae" of a few days, at the end of which period, an acknowledgment before a notary would be used to render the instrument legally

32 Note 30 supra.

${ }^{33}$ Williams v. Galt might be explainable in the light of a mercantile policy in favor of transferability.

${ }^{34}$ See, The Trustees of the Danver's Literary \& Library Association v. Skaggs, $280 \mathrm{Il}$. App. I25 (I935) (where it was held that the note was delivered by the maker though he retained possession of it, since he had placed the note among the payee's papers which were in his possession as agent, with the intention of delivering it). See also, Shaw v. Camp, r6o $\mathrm{Ml} .425$, 43 N.E. 608 ( 1896$)$.

${ }^{35}$ Note 30 supra. $\quad{ }^{36}$ Note 5 supra. $\quad{ }^{37}$ Note 6 supra.

${ }^{38} 2$ I Ill. L. Rev. I85, I86 (I926) (note). 
operative. ${ }^{39}$ But requiring an acknowledgment would, in effect, be substituting one formalism for another, ${ }^{40}$ and would in some cases not carry out the intention of the obligor. For example, would the promisor have a defense in the following case? The promisor has made a gratuitous written promise, acknowledged it before a notary and placed the instrument somewhere for safekeeping, not intending to put it into legal effect until some later period; in the interim, the promisee brings suit. No one act should be of itself sufficient to bind the promisor; his intention, as determined from all his acts, should be of paramount importance. Consequently a more practical means by which to obtain the results intended would be to require a "delivery" of the instrument analogous to that required in the law of deeds, contracts under seal, and bills and notes..$^{4}$

39 Ibid., at $187 . \quad{ }^{10} 29$ Col. L. Rev. 206, 208 (1929).

4I It is possible that the Uniform Written Obligations Act would be clearer if it contained some such provision as the following: "An instrument governed by the provisions of this Act shall not become effective in creating or discharging an obligation except upon delivery. A manifestation of intention to make such an instrument effective shall be necessary and sufficient to constitute delivery." 